\title{
Infeksi Cacing Tidak Berpengaruh terhadap Kadar Transforming Growth Factor (TGF)-6 dan Kejadian Dermatitis Atopik pada Anak
}

\section{Helminths Infection do not Affect Transforming Growth Factor (TGF)-B Levels and the Occurency of Atopic Dermatitis in Children}

\author{
Nadiah Soleman $M^{1}$, Sitti Wahyuni', Faridha S Ilyas ${ }^{1}$, Safruddin Amin ${ }^{1}$, R Satriono ${ }^{3}$, Farida Tabri ${ }^{1}$ \\ ${ }^{1}$ Bagian IImu Kesehatan Kulit dan Kelamin Fakultas Kedokteran Universitas Hasanuddin Makasar \\ ${ }^{2}$ Bagian Parasitologi Fakultas Kedokteran Universitas Hasanuddin Makasar \\ ${ }^{3}$ Bagian Ilmu Kesehatan Anak Fakultas Kedokteran Universitas Hasanuddin Makasar
}

\begin{abstract}
ABSTRAK
Infeksi cacing melalui kemampuannya memacu proliferasi sel T regulator dilaporkan dapat mempengaruhi manifestasi klinik dari alergi. Selain Interleukin (IL)-10, Transforming Growth Factor (TGF)-B merupakan sitokin yang di lepaskan oleh sel T regulator. Penelitian ini bertujuan untuk melihat pengaruh infeksi cacing terhadap kejadian dermatitis atopik (DA) melalui TGF-6. Penelitian ini dilakukan di beberapa rumah sakit pendidikan Fakultas Kedokteran Universitas Hasanuddin. Dermatitis atopik (DA) didiagnosis dengan menggunakan kriteria William, ada dan beratnya infeksi cacing diperiksa dengan metode Kato Katz dan kadar TGF-B serum diukur menggunakan metode ELISA. Sebanyak 80 anak usia 2-7 tahun berpartisipasi pada penelitian ini. Partisipan dibagi menjadi kelompok DA (30 anak) dan non-DA (50 anak). Persentasi infeksi cacing adalah 21,2\% (17/80) dengan intensitas infeksi yang ringan. Infeksi cacing tidak mempengaruhi kadar TGF-B, demikian juga infeksi cacing serta kadar TGF- 6 tidak mempengaruhi kejadian DA. Penelitian ini menyimpulkan bahwa infeksi cacing dengan intensitas ringan tidak mempengaruhi kadar TGF- 8 maupun kejadian DA pada anak di Makassar.
\end{abstract}

Kata Kunci: Dermatitis atopik, infeksicacing, TGF-B

\begin{abstract}
Helminths infections through the ability to stimulate the proliferation of regulatory $T$ cells have been reported to affect the clinical manifestations of allergy. Besides Interleukin (IL)-10, Transforming Growth Factor (TGF)-6 is cytokine released by regulatory $T$ cells. This study is aimed to examine the effect of helminths infection on atopic dermatitis (AD) occurrence through TGF-b. This study was conducted in several teaching hospitals of Medical Faculty Hasanuddin University. Atopic dermatitis ( $A D)$ was diagnosed by using William criteria, the presence and severity of helminths infections were examined by Kato Katz methods, and serumTGF-6 levels were measured by ELISA methods. A total of 80 children ranging from 2 to 7 years old participated in this study. The participants were divided into DA group(30 children) and non DA group (50 children). The percentage of helminths infection was 21,2\% (17/80) with light infection intensity. Helminths infection did not affect TGF-B levels and the occurrence of $A D$. This study concludes that light intensity of helminths infection did not affect the levels of TGF- $B$ as well as the occurrence of $A D$ in children in Makassar.
\end{abstract}

Keywords: Atopic dermatitis, helminths infection, TGF-B

Jurnal Kedokteran Brawijaya, Vol. 28, No. 3, Februari 2015; Korespondensi: Nadiah Soleman M. Fakultas Kedokteran Universitas Hasanuddin Makasar, Jl. Perintis Kemerdekaan 11 Tamalanrea, Makassar 90245 Tel. (0411) 580687Email: solemannadia@yahoo.co.id 


\section{PENDAHULUAN}

Dermatitis atopik (DA) atau eksema merupakan suatu inflamasi pada kulit yang kronis disertai rasa gatal, terjadi secara menahun, hilang timbul dan umumnya muncul pada masa bayi, meningkat pada masa anak anak dan menghilang pada usia remaja (1). Penelitian yang dilakukan di Amerika memperlihatkan bahwa DA merupakan salah satu gangguan kulit yang paling umum terlihat pada bayi dan anak-anak, mulai ditemukan pada 6 bulan pertama kehidupan pada $45 \%$ dari anak-anak, terjadi pada tahun pertama kehidupan pada $60 \%$ dari individu yang terkena, dan mulai terjadi sebelum usia 5 tahun pada setidaknya $85 \%$ dari individu yang terkena (2). Hanya sekitar 1-3\% DA yang timbul pertama kali antara usia 6 sampai 20 tahun (3) dan sangat jarang muncul pada usia dewasa. Sebanyak $60 \%$ orangtua yang menderita dermatitis atopik, mempunyai anak yang juga menderita penyakit yang sama dan prevalensi DA meningkat menjadi 80\% apabila kedua orangtuanya menderita DA (3).

Departemen kesehatan pada tahun 2011 melaporkan bahwa prevalensi DA di Indonesia adalah $86 \%$ diantara 192.414 kasus penyakit kulit di beberapa Rumah Sakit Umum (4). Di Makassar, data Rekam Medis RS Wahidin Sudirohusodo dan RS Pelamonia di Makassar menunjukkan adanya peningkatan jumlah kasus DA anak dari tahun ke tahun dimana pada tahun 2004 dilaporkan ada 47 kasus, tahun 2005 terdapat 106 kasus, tahun 2006 terdapat 108 kasus dan tahun 2007 terdapat 115 anak kasus (5). Dari seluruh kunjungan anak pada poliklinik kulit dan kelamin RS Wahidin Sudirohusodo, terdapat 16,34\% yang mengalami DA.

Terdapat banyak faktor yang dianggap berperan terhadap kejadian DA yaitu antara lain faktor genetik, disfungsi sawar kulit, imunologis, lingkungan, dan psikologis (6) Selain itu, riwayat atopi pada organ lain seperti rinitis alergi, asma pada penderita maupun keluarganya dilaporkan mempengaruhi kejadian DA pada seseorang (3). Dibandingkan dengan negara maju, prevalensi alergi termasuk DA ditemukan jauh lebih rendah di negara yang sedang berkembang (7) Asosiasi negatif antara infeksi cacing dan kejadian alergi telah dilaporkan dari berbagai penelitian yang dilakukan di negara tropis. Di Equador, infeksi Ascaris dan Necator berbanding terbalik dengan skin prick test positivity (8). Di Brazil, kejadian asma ditemukan lebih sedikit pada mereka yang terinfeksi oleh Schistosoma (9). Penelitian serupa di lakukan pada kasus Asma bronchial di Papua Nugini (10) dan dermatitis atopik di Kuba (1). Hasil penelitian itu mengidentifikasi hubungan negatif asma dan dermatitis atopi dengan infeksi Ascaris lumbricoides. Review yang dilakukan pada berbagai tulisan yang meneliti infeksi cacing dan alergi menyimpulkan bahwa infeksi cacing yang kronik menginduksi pelepasan sitokin anti inflamasi yaitu IL-10 dan TGF- $\beta$ (11).

Interleukin (IL)-10 dan TGF-B merupakan sitokin yang mempunyai kemampuan menurunkan inflamasi. Sitokin ini diproduksi oleh sel T regulator (12). Induksi dari sel T regulator dapat mengurangi efek inflamasi akibat infeksi kronik oleh virus (13), bakteri $(14,15)$, protozoa (16) dan maupun infeksi cacing (17). Indonesia merupakan Negara dengan infeksi cacing yang cukup tinggi. Hasil survei
Subdit Diare pada tahun 2002 dan 2003 pada 40 SD di sepuluh propinsi menunjukkan prevalensi berkisar antara $2,2 \%-96,3 \%$ (18). Suatu penelitian yang mengumpulkan data penelitian cacing di Indonesia sejak tahun 1970 melaporkan bahwa di Indonesia spesies cacing yang terbanyak ditemukan adalah Ascaris lumbricoides (14\%90\%), Trichuris trichiura (1\%-90\%), dan Ankylostoma duodenale/Necator americanus (18\%-76\%) (19).

Penelitian yang menghubungkan antara infeksi cacing, IL10 dan alergi sudah banyak dilakukan. Sebaliknya, informasi bagaimana infeksi cacing melalui modulasi TGF$\beta$ mempengaruhi kejadian alergi masih sangat terbatas. Penelitian ini bertujuan untuk mengetahui pengaruh infeksi cacing terhadap kadar TGF- 6 serum dan dermatitis atopik pada pasien anak di Makassar.

\section{METODE}

Penelitian ini dirancang secara cross sectional. Populasi penelitian ini adalah pasien umur 2-7 tahun yang berkunjung di poliklinik Kulit dan Kelamin di beberapa rumah sakit pendidikan Fakultas Kedokteran Universitas Hasanuddin. Setelah dilakukan informed consent dan orang tua menandatangani persetujuan penelitian, orang tua partisipan diminta untuk menjawab pertanyaan yang berhubungan dengan umur dan riwayat penyakit yang dialami oleh pasien. Partisipan dikelompokkan menjadi kelompok DA dan kelompok non DA. Partisipan dinyatakan DA jika memenuhi kriteria William yaitu jika terdapat keluhan gatal pada kulit yang disertai dengan minimal 3 kriteria berikut: 1) onset gatal pertama kali terjadi di bawah usia 2 tahun (kriteria ini hanya digunakan pada anak usia 4 tahun atau lebih), 2) riwayat gatal yang melibatkan lipatan kulit seperti lipatan siku, belakang lutut, depan sendi kaki dan sekitar leher (atau pipi jika anak dibawah 2 tahun); 3) riwayat atopi lain seperti sesak atau rinitis (pada anak di bawah usia 4 tahun), 4) riwayat kekeringan kulit pada tahun terakhir, 5) eksim di fleksural yang nyata (eksim termasuk pada pipi, dahi, dan bagian luar ekstremitas pada anak di bawah usia 4 tahun) (20).

Sebanyak $3 \mathrm{ml}$ darah diminta dari tiap partisipan untuk pemeriksaan kadar TGF- $B$ serum. Kadar TGF- $B$ diperiksa dengan menggunakan kit R\&D system (Quantikine ELISA Human TGF-B) dan diukur dengan teknik ELISA. Kadar TGF$\beta$ serum dinyatakan meningkat jika kadarnya $\geq 40.000 \mathrm{pg} / \mathrm{ml}$. sampel tinja sebanyak kurang lebih 1 sendok teh dikumpulkan dari setiap partisipan untuk melihat ada tidaknya infeksi cacing. Metode Kato-katz digunakan untuk menentukan beratnya infeksi. Infeksi dinyatakan berat jika dalam setiap gram tinja ditemukan telur Ascaris lumbricoides, Trichuris trichiura dan cacing tambang masing masing $\geq 50.000, \geq 10.000$ dan $\geq 4.000$; infeksi sedang jika jumlah telur $A$. lumbricoides, T. trichiura dan cacing tambang masing masing 5.000-49.999, 1.0009.999 dan 2.000-3.999; dan infeksi ringan jika jumlah telur A. lumbricoides, $T$. trichiura dan cacing tambang masingmasing $\leq 4.999$, $\leq 999$ dan $\leq 999$ epg (20).

Pengaruh infeksi cacing terhadap kadar TGF-B serum dan pengaruh berbagai faktor terhadap kejadian DA dianalisa dengan menggunakan Fisher exact test. Suatu variabel dianggap berpengaruh terhadap variabel lain jika $p<0,05$. 


\section{HASIL}

Penelitian dilakukan pada bulan Januari-Maret 2014.

Jumlah pasien yang berpartisipasi pada penelitian adalah 80 orang anak usia 2 sampai 7 tahun dengan usia rerata $6,24( \pm 0,89)$ tahun. Partisipan terdiri atas 47 anak laki-laki $(58,8 \%)$ dan diantara 80 anak, 30 anak dinyatakan DA (37,5\%). Infeksi cacing ditemukan pada 17 anak dengan infeksi Ascaris lumbricoides 3 orang, Trichuris 6 orang, cacing tambang 5 orang, infeksi campuran Ascaris dan cacing tambang 2 orang, dan infeksi campuran Trichuris dan cacing tambang 1 orang. Intensitas infeksi pada seluruh anak yang mengalami infeksi cacing tergolong ringan untuk semua spesies cacing. Kadar TGF-6 Serum yang didapatkan adalah $21828-79535 \mathrm{pg} / \mathrm{ml}$ dengan nilai rerata $46646,01 \pm 12887,98 \mathrm{pg} / \mathrm{ml}$ (Tabel 1 ).

Tabel 1. Karakteristik partisipan

\begin{tabular}{ccc}
\hline \multicolumn{1}{c}{ Karakteristik } & $\mathbf{N}=\mathbf{8 0}$ & $\%$ \\
\hline Usia & & \\
$\leq 5$ tahun & 10 & 12,50 \\
$\quad>5$ tahun & 70 & 87,50 \\
Jenis Kelamin & & \\
$\quad$ Laki-laki & 47 & 58,70 \\
$\quad$ Perempuan & 33 & 41,30 \\
Dermatitis atopi & & \\
$\quad$ Positif & 30 & 37,50 \\
$\quad$ Negatif & 50 & 62,50 \\
Infeksi cacing & & \\
$\quad$ Positif & 17 & 21,30 \\
$\quad$ Negatif & 63 & 78,70 \\
Kadar TGF- $\boldsymbol{\beta}$ & & \\
Normal $(<40,000 \mathrm{pg} / \mathrm{ml})$ & 22 & 27,50 \\
Tinggi $(\geq 40,000 \mathrm{pg} / \mathrm{ml})$ & 58 & 72,50 \\
\hline
\end{tabular}

Keterangan: TGF- $b=$ Transforming Growth Factor $B$

Pengaruh infeksi cacing pada kadar TGF- 6 serum dianalisa dengan menggunakan Fisher exact test. Pada Tabel 2 terlihat, infeksi cacing tidak memberikan perbedaan kadar TGF-B.

Tabel 2. Pengaruh infeksi cacing terhadap kadar TGF- 6 pada pasien dengan kelainan kulit umur 2-7 tahun

\begin{tabular}{ccccc}
\hline & \multicolumn{2}{c}{ Kadar TGF- $\boldsymbol{\beta}$} & & \\
\cline { 2 - 3 } & $\begin{array}{c}\text { Tinggi } \\
(\mathbf{n}=58)\end{array}$ & $\begin{array}{c}\text { Normal } \\
(\mathbf{n}=\mathbf{2 2})\end{array}$ & $\boldsymbol{P}$ & OR(95\%Cl) \\
\hline $\begin{array}{c}\text { Infeksi cacing } \\
\text { Positif }\end{array}$ & 12 & 5 & 0,842 & $0,89(0,27-2,89)$ \\
Negatif & 46 & 17 & & \\
\hline
\end{tabular}

Keterangan: Fisher exact test; TGF- $\mathrm{B}=$ Transforming Growth Factor $\mathrm{B}$

Untuk mengetahui faktor-faktor yang berpengaruh pada kejadian dermatitis atopik, berbagai variabel yang mungkin mempengaruhi dianalisa dengan menggunakan Fisher exact test. Seperti terlihat pada Tabel 3, infeksi cacing dan kadar TGF- 8 maupun umur dan jenis kelamin tidak berpengaruh secara sigifikan terhadap kejadian dermatitis atopi.
Tabel 3. Pengaruh berbagai faktor terhadap kejadian dermatitis atopik pada pasien dengan kelainan kulit umur 2-7 tahun

\begin{tabular}{|c|c|c|c|c|}
\hline \multirow[b]{2}{*}{ Variabel } & \multicolumn{2}{|c|}{ Dermatitis Atopik } & \multirow[b]{2}{*}{$\mathbf{P}$} & \multirow[b]{2}{*}{ OR (Cl 95\%) } \\
\hline & $\begin{array}{c}Y a \\
(n=30)\end{array}$ & $\begin{array}{c}\text { Tidak } \\
(n=60)\end{array}$ & & \\
\hline \multicolumn{5}{|l|}{ Infeksi cacing } \\
\hline Positif & 4 & 13 & 0,157 & $2,28(0,67-7,79)$ \\
\hline Negatif & 26 & 37 & & \\
\hline \multicolumn{5}{|l|}{ Kadar TGF- $\boldsymbol{\beta}$} \\
\hline $\begin{array}{l}\text { Normal } \\
\qquad(<40,000 \mathrm{pg} / \mathrm{ml})\end{array}$ & 5 & 17 & 0,099 & $0,39(0,13-1,19)$ \\
\hline \multicolumn{5}{|l|}{ Tinggi } \\
\hline$(\geq 40,000 \mathrm{pg} / \mathrm{ml})$ & 25 & 33 & & \\
\hline \multicolumn{5}{|l|}{ Umur } \\
\hline$\leq 5$ tahun & 1 & 9 & 0,087 & $0,16(0,02-1,31)$ \\
\hline$>5$ tahun & 29 & 41 & & \\
\hline \multicolumn{5}{|l|}{ Jenis Kelamin } \\
\hline Laki-laki & 21 & 26 & 0,116 & $0,46(0,18-1,21)$ \\
\hline Perempuan & 9 & 24 & & \\
\hline
\end{tabular}

Keterangan: Fisher exact test; TGF- $8=$ Transforming Growth Factor $\beta$

\section{DISKUSI}

Infeksi cacing yang terjadi secara kronik berinteraksi dengan sistem imun adaptif dari inang yang ditempatinya dengan meregulasi respons sel T dan sel B melalui induksi sel Treg yang kemudian melepaskan sitokin anti inflamasi seperti IL-10 dan TGF-B (22). Kejadian alergi jarang ditemukan pada individu yang terinfeksi secara kronik oleh cacing karena respon imun tipe Th2 diimbangi dengan oleh pelepasan sitokin anti inflamasi seperti IL-10 dan TGF- 6 dan kondisi ini tidak ditemukan jika infestasi cacing tidak kronik (23). Aktifasi sel T regulator merupakan mekanisme tubuh untuk mengimbangi proses inflamasi yang berlangsung kronik karena cacing pada umumnya membutuhkan inang untuk waktu yang lama. Pada penderita onchocerciasis misalnya, sel Treg terhadap antigen Onchocerca dapat diisolasi dan peningkatan jumlah sel ini disertai dengan peningkatan kadar IL-10 dan atau TGF-B. Jumlah sel $\mathrm{T}$ efektor pada penderita ini dilaporkan rendah (24).

Kadar TGF- 6 pada penelitian ini tidak dipengaruhi oleh infeksi cacing. Proporsi anak yang mengalami peningkatan kadar TGF- 6 pada mereka yang terinfeksi cacing dan tidak terinfeksi cacing, tidak berbeda yaitu masing-masing $70,0 \%$ (12/17) dan 73,2\% (46/63). Terdapat laporan yang menunjukkan bahwa infeksi cacing yang berkelanjutan melalui aktivasi dari sel Treg dapat meningkatkan kadar IL10 dan TGF-B. Meskipun demikian, dibandingkan TGF-6, sitokin IL-10 mempunyai peran utama terhadap penekanan inflamasi akibat infeksi cacing (25). Kemungkinan, intensitas infeksi cacing yang umumnya ringan pada populasi penelitian ini tidak cukup kuat untuk menginduksi pelepasan TGF- 8 . Kemungkinan lainnya adalah infeksi cacing bukan infeksi kronik tetapi infeksi akut.

Pada penelitian ini juga tidak ditemukan hubungan yang bermakna antara infeksi cacing dan kejadian DA. Hal ini dapat disebabkan karena intensitas infeksi cacing tidak cukup kuat untuk menginduksi pelepasan TGF- 6 sehingga efek infeksi cacing tidak dapat mempengaruhi kejadian 
dermatitis atopik. Pada penelitian yang dilakukan di Ethiopia juga ditemukan bahwa infeksi Ascaris tidak mempengaruhi sensitifitas terhadap aero alergen (26) dan infeksi cacing tambang tidak mempengaruhi kejadian asma (27). Kedua penelitian tersebut dilakukan pada anak dengan intensitas infeksi cacing yang ringan. Menariknya, dalam penelitian ini ditemukan bahwa proporsi anak yang menderita cacing pada kelompok DA lebih kecil dari pada kelompok bukan DA (tabel 3) yaitu masing masing 13,3\% (4/30) dan 26,6\% (13/37) yang menandakan bahwa kecenderungan untuk mengalami DA lebih banyak ditemukan pada mereka yang tidak terinfeksi cacing.

Proporsi anak dengan kadar TGF- 6 yang tinggi ditemukan lebih banyak pada kelompok dermatitis atopik dibanding yang bukan dermatitis atopik (Tabel 3) yaitu masing masing $83 \%$ (25/30) dan 66\% (33/50). Hal ini menimbulkan pertanyaan apakah TGF- 6 yang terukur pada penelitian ini merupakan respon yang terjadi untuk mengimbangi produksi sitokin inflamasi tipe Th2 mengingat bahwa sitokin yang dilaporkan lebih berperan dalam menekan inflamasi pada infeksi cacing adalah IL-10 dan bukan TGF-6 (25). Perlu dilakukan penelitian yang sama namun disertai pengukuran IL-10 untuk menjawab pertanyaan tersebut.

Penelitian ini merupakan penelitian pertama yang mencoba menghubungkan pengaruh infeksi cacing

\section{DAFTAR PUSTAKA}

1. Wördemann M, Diaz RJ, Heredia LM, et al. Association of Atopy, Asthma, Allergic Rhinoconjunctivitis, Atopic Dermatitis and Intestinal Helminth Infections in Cuban Children. Tropical Medicine and International Health. 2008; 13(12): 180-186.

2. Paller A and Mancini A. Hurwitz Clinical Pediatric Dermatology. Chicago: Elsevier Saunder; 2011; p. 3752.

3. Leung D, Eichenfield L, and Boguniewicz M. Atopic Dermatitis (Atopic Eczema). In: Wolff K, Goldsmith L, Katz S, Gilchrest B, Paller A, and Leffell D (Eds). Fitzpatrick's Dermatology in General Medicine 7th ed. New York: Mc GrawHill; 2008; p. 146-158.

4. Departemen Kesehatan. Profil Kesehatan Republik Indonesia Tahun 2010. Jakarta: Kementrian Kesehatan RI; 2011.

5. Daftar Kunjungan Poliklinik Kulit dan Kelamin Rumah Sakit Pelamonia. [Tidak Diterbitkan].

6. Leung D, Eichenfield FL, and Boguniewicz M. Atopic Dermatitis. In: Lowell AG, Stephen IK, Barbara AG, Amy SP, and David JL (Eds). Fitzpatrick's Dermatology in General Medicine. New York: Mc GrawHill; 2012; p. 261-283.

7. No Author Listed. Worldwide Variation in Prevalence of Symptoms of Asthma, Allergic Rhinoconjunctivitis, and Atopic Eczema: ISAAC. The International Study of Asthma and Allergies in Childhood (ISAAC) Steering Committee. The Lancet. 1998; 351(9111): 1225-1232.

8. Cooper PJ, Chico ME, Rodrigues LC, et al. Reduced Risk of Atopy among School-Age Children Infected with Geohelminth Parasites in A Rural Area of the Tropics. Journal of Allergy and Clinical Immunology. 2003; melalui TGF-B terhadap kejadian dermatitis atopi. Untuk mencari hubungan antara infeksi cacing dan alergi, intensitas infeksi cacing yang sedang hingga berat mungkin perlu dipertimbangkan ketika memilih populasi penelitian. Selain itu, kadar IL-10 perlu diukur bersama sama dengan TGF-B ketika melakukan investigasi untuk menganalisa ada tidaknya pengaruh infeksi cacing terhadap kejadian alergi. Secara keseluruhan penelitian ini menyimpulkan bahwa infeksi cacing dengan intensitas ringan tidak mempengaruhi secara signifikan kadar TGF- 6 maupun kejadian dermatitis atopik pada anak umur 2-7 tahun yang berkunjung di rumah sakit pendidikan Universitas Hasanuddin, Makassar.

\section{UCAPAN TERIMA KASIH}

Terima kasih ditujukan kepada pasien anak dan orang tuanya yang berpartisipasi pada penelitian ini. Terima kasih juga ditujukan kepada Uli dan Risma yang membantu pemeriksaan TGF-B, kepada Ibu Asni dari Bagian Parasitologi yang melakukan pemeriksaan mikroskopik, kepada teman teman residen di Bagian Kulit Kelamin Fakultas Kedokteran Universitas Hasanuddin atas bantuannya dalam merekrut partisipan dan kepada Laboratorium Penelitian RS. Universitas Hasanuddin (Hasanuddin University Medical Research Center-HUMRC) tempat dimana pemeriksaan ELISA dilakukan.

\section{1(5): 995-1000.}

9. Medeiros M Jr., Figueiredo JP, Almeida MC, et al. Schistosoma Mansoni Infection is Associated with a Reduced Course of Asthma. Journal of Allergy and Clinical Immunology. 2003; 111(5): 947-951.

10. Shield JM, Scrimgeour EM, and Vaterlaws AL. Intestinal Helminths in an Adult Hospital Population in the Eastern Highlands of Papua New Guinea: Relationship with Anemia, Eosinophilia, and Asthma. Papua and New Guinea Medical Journal. 1980; 23(4): 157-164.

11. Yazdanbakhsh M, van den BA, and Maizels RM. Th2 Responses Without Atopy: Immunoregulation in Chronic Helminth Infections and Reduced Allergic Disease. Trends in Immunology. 2001; 22(7): 372-377.

12. Groux $\mathrm{H}$ and Powrie F. Regulatory $T$ Cells And Inflammatory Bowel Disease. Immunology Today. 1999; 20(10): 442-445.

13. Iwashiro M, Messer RJ, Peterson KE, Stromnes IM, Sugie T, and Hasenkrug KJ. Immunosuppression by CD41 Regulatory T Cells Induced by Chronic Retroviral Infection. Proceeding of the National Academy of Sciences of the United Statesof America. 2001; 98(16): 9226-9230.

14. Kullberg MC, Jankovic D, Gorelick PL, et al. BacteriaTriggered CD4+ T Regulatory Cells Suppress Helicobacter Hepaticus-Induced Colitis. Journal of Experimental Medicine. 2002; 196(4): 505-515.

15. McGuirk P, McCann C, and Mills KHG. PathogenSpecific T Regulatory 1 Cells Induced in the Respiratory Tract by a Bacterial Molecule that Stimulates Interleukin 10 Production by Dendritic Cells: A Novel Strategy for Evasion of Protective T Helper Type 1 Responses by Bordetella Pertussis. Journal of Experimental Medicine. 2002; 195(2): 221-231. 
16. Hisaeda H, Maekawa Y, Iwakawa D, et al. Escape of Malaria Parasites from Host Immunity Requires CD4+CD25+ Regulatory $T$ Cells. Nature Medicine. 2004; 10(1): 29-30.

17. Schopf LR, Hoffmann KF, Cheever AW, Urban JF Jr, and Wynn TA. IL-10 is Critical for Host Resistance and Survival During Gastrointestinal Helminth Infection. The Journal of Immunology. 2002; 168(5): 2383-2392.

18. Departemen Kesehatan. Pedoman Pengendalian Cacingan. Jakarta: Kementerian Kesehatan RI; 2006.

19. Wahyuni S. Helminth Infections, Allergic Disorders and Immune Responses: Studies in Indonesia. Leiden University, Netherlands. 2006.

20. Friedmann $P$, Holden $C$, and Ardern-Jones MR. Atopic Dermatitis. In: Burns T, Breathnach S, Cox N, and Griffiths C (Ed). Rook's Textbook of Dermatology 8th ed. Oxford: Wiley Blackwell.; 2010; p. 24.1-24.34.

21. World Health Organization, Parasitic Diseases Programme. Diagnostic Techniques for Intestinal Parasitic Infections (IPI) Applicable to Primary Health Care (PHC) Services. Geneva, Switzerland: World Health Organization; 1985.
22. Van Riet E, Hartger F, and Yazdanbakhsh M. Chronic Helminth Infections Induce Immunomodulation: Consequences and Mechanisms. Immunobiology. 2007; 212(6): 475-490.

23. Cooper PJ. Can Intestinal Helminth Infections (Geohelminths) Affect the Development and Expression of Asthma and Allergic Disease? Clinical and Experimental Immunology. 2002; 128(3): 398404.

24. Smits H, Hartgers F, and Yazdanbakhsh M. Helminth Infections: Protection from Atopic Disorders. Current Allergy and Asthma Reports. 2005; 5(1): 42-50.

25. Flohr C. Dirt, Worms, and Atopic Dermatitis. British Journal of Dermatology. 2003; 148(5): 871-877.

26. Selassie FG, Steven RH, Cullinan $P$, et al. Total and Specific Ige (House Dust Mite and Intestinal Helminths) in Asthmatics and Controls from Gondar, Ethiopia. Clinical \& Experimental Allergy. 2000;30(3):356-358.

27. Davey G, Venna A, Belete H, Berhane Y, and Britton J. Wheeze, Allergic Sensitization and Geohelminth Infection in Butajira, Ethiopia. Clinical \& Experimental Allergy. 2005; 35(3): 301-307. 